\title{
Characteristics of Carbon Monoxide Oxidization in Rich Hydrogen by Mesoporous Silica with $\mathrm{TiO}_{2}$ Photocatalyst
}

\author{
Akira Nishimura, ${ }^{1}$ Yutaka Yamano, ${ }^{1}$ Tomokazu Hisada, ${ }^{1}$ Masafumi Hirota, ${ }^{1}$ and Eric $\mathrm{Hu}^{2}$ \\ ${ }^{1}$ Division of Mechanical Engineering, Graduate School of Engineering, Mie University, 1577 Kurimamachiya-cho, Tsu 514-8507, Japan \\ ${ }^{2}$ School of Mechanical Engineering, The University of Adelaide, Adelaide, SA 5005, Australia \\ Correspondence should be addressed to Akira Nishimura, nisimura@mach.mie-u.ac.jp
}

Received 17 August 2010; Accepted 9 November 2010

Academic Editor: Jimmy Yu

Copyright (C) 2010 Akira Nishimura et al. This is an open access article distributed under the Creative Commons Attribution License, which permits unrestricted use, distribution, and reproduction in any medium, provided the original work is properly cited.

\begin{abstract}
Hydrogen $\left(\mathrm{H}_{2}\right)$ is normally used as the fuel to power polymer electrolyte fuel cell (PEFC). However, the power generation performance of PEFC is harmed by the carbon monoxide $(\mathrm{CO})$ in the $\mathrm{H}_{2}$ that is often produced from methane $\left(\mathrm{CH}_{4}\right)$. The purpose of this study is to investigate the experimental conditions in order to improve the $\mathrm{CO}$ oxidization performance of mesoporous silica loaded with $\mathrm{TiO}_{2}$. The impact of loading ratio of $\mathrm{TiO}_{2}$ and initial concentration ratio of $\mathrm{O}_{2}$ to $\mathrm{CO}$ on $\mathrm{CO}$ oxidization performance is investigated. As a result, the optimum loading ratio of $\mathrm{TiO}_{2}$ and initial concentration ratio of $\mathrm{O}_{2}$ to $\mathrm{CO}$ were $20 \mathrm{wt} \%$ and $4 \mathrm{vol} \%$, respectively, under the experimental conditions. Under this optimum experimental condition, the $\mathrm{CO}$ in rich $\mathrm{H}_{2}$ in the reactor can be completely eliminated from initial $12000 \mathrm{ppmV}$ after UV light illumination of 72 hours.
\end{abstract}

\section{Introduction}

Polymer electrolyte fuel cell (PEFC) has been developed vigorously in the world since it is an attractive and clean power generation technology. $\mathrm{H}_{2}$ is normally used as the fuel to power PEFC. However, the reduction of PEFC power generation performance has been observed due to the existence of $\mathrm{CO}$ in the $\mathrm{H}_{2}$ produced from $\mathrm{CH}_{4}, \mathrm{CH}_{3} \mathrm{OH}$, and gasoline.

$\mathrm{CH}_{4}$ is normally the feedstock to produce $\mathrm{H}_{2}$ with $\mathrm{Ni}$ or $\mathrm{Ru}$ as catalyst at the high temperature range of $873 \mathrm{~K}-973 \mathrm{~K}$ through the following reaction:

$$
\mathrm{CH}_{4}+\mathrm{H}_{2} \mathrm{O} \longrightarrow \mathrm{CO}+3 \mathrm{H}_{2}
$$

After this reaction, there is about $10 \mathrm{vol} \%$ of $\mathrm{CO}$ in the products. The $\mathrm{CO}$ concentration can be reduced down to about 1 vol\% by the following so-called shift reaction:

$$
\mathrm{CO}+\mathrm{H}_{2} \mathrm{O} \longrightarrow \mathrm{CO}_{2}+\mathrm{H}_{2}
$$

After the shift reaction, the concentration of $\mathrm{CO}$ needs to be further reduced down to $10 \mathrm{ppmV}$ by the following selective oxidization reaction:

$$
\mathrm{CO}+\frac{1}{2} \mathrm{O}_{2} \longrightarrow \mathrm{CO}_{2}
$$

In the $\mathrm{H}_{2}$ purification processes mentioned above, precious metal catalysts and thermal energy are used, and the processes are costly. An alternative process, that is, using the $\mathrm{TiO}_{2}$ photocatalyst combined with adsorbent to oxidize $\mathrm{CO}$ is being developed recently due to its potential cost and energy saving.

$\mathrm{TiO}_{2}$ can oxidize $\mathrm{CO}$ under illumination of ultraviolet (UV) ray (available in sunlight) through the following reaction scheme $[1,2]$.

Photocatalytic reaction:

$$
\mathrm{TiO}_{2}+h v(<380 \mathrm{~nm}) \longrightarrow \mathrm{h}^{+}+\mathrm{e}^{-} .
$$

Oxidization of CO:

$$
\mathrm{CO}+\mathrm{h}^{+} \longrightarrow \mathrm{CO}^{+} .
$$


Reduction of $\mathrm{O}_{2}$ :

$$
\begin{gathered}
\mathrm{O}^{2}+\mathrm{e}^{-} \longrightarrow \mathrm{O}_{2}^{-}, \\
\mathrm{O}_{2}^{-}+\mathrm{h}^{+} \longrightarrow 2 \mathrm{O}, \\
\mathrm{O}+\mathrm{e}^{-} \longrightarrow \mathrm{O}^{-} .
\end{gathered}
$$

From the products of the reactions (5) and (8), the following combined reaction occurs:

$$
\mathrm{CO}^{+}+\mathrm{O}^{-} \longrightarrow \mathrm{CO}_{2} \text {. }
$$

Therefore, the total reaction scheme can be written as follows:

$$
\mathrm{CO}+\frac{1}{2} \mathrm{O}_{2} \longrightarrow \mathrm{CO}_{2}
$$

where $h v$ is the energy of UV ray. $\mathrm{h}^{+}$and $\mathrm{e}^{-}$represent the hole and electron produced by photocatalytic reaction, respectively.

The oxidization process with $\mathrm{TiO}_{2}$ has the following merits. (1) There is a lot of $\mathrm{TiO}_{2}$ reserve in the earth compared with precious metal catalyst. The amount of $\mathrm{Ti}$ is the 9th largest among the elements consisting the earth crust [3]. (2) Cost is lower than using precious metal catalyst. (3) Energy consumption is less and the control of the reaction process is easier since high thermal energy is not necessary. (4) Solar energy can be used for the reaction. (5) $\mathrm{TiO}_{2}$ is stable in both acid and alkali environments.

Literature survey shows that $\mathrm{TiO}_{2}$ photocatalyst combined with adsorbent such as activated carbon, zeolite, and silica $\left(\mathrm{SiO}_{2}\right)$ was mainly used in environmental purification technologies such as $\mathrm{NO}_{x}$ removal [4-6], decomposition of acetaldehyde [7], dimethylsulfide [8], 2-propoanol [9], degradation of organophosphate and phosphonoglycine [10], and $\mathrm{CO}_{2}$ reforming into fuel like $\mathrm{CH}_{4}$ and $\mathrm{CH}_{3} \mathrm{OH}$ $[11,12]$. The $\mathrm{CO}$ oxidization by photocatalyst combined with $\mathrm{FeO}_{x}, \mathrm{AL}_{2} \mathrm{O}_{3}$, or $\mathrm{CeO}_{x}$ and precious metal catalyst like $\mathrm{Pt}$ or Au was reported [13-15]. Furthermore, the CO oxidization characteristics of Pt loaded on zeolite without photocatalyst were also reported $[16,17]$. Although there are reports on the $\mathrm{CO}$ oxidization characteristics of $\mathrm{Mo} / \mathrm{SiO}_{2}$ or $\mathrm{Cr} / \mathrm{SiO}_{2}[18,19]$, there is no report on the $\mathrm{CO}$ oxidization characteristics of $\mathrm{TiO}_{2}$ combined with adsorbent except our previous study [20]. Our previous study investigated the effect of different loading methods of $\mathrm{TiO}_{2}$ to silica on $\mathrm{CO}$ oxidization performance. Comparing two types of $\mathrm{TiO}_{2}$ particle combined with silica, that is, the silica gel particles coated with $\mathrm{TiO}_{2}$ film and mesoporous silica particles loaded with $\mathrm{TiO}_{2}$, the amount of oxidized $\mathrm{CO}$ per unit mass of $\mathrm{TiO}_{2}$ for the mesoporous silica particles loaded with $\mathrm{TiO}_{2}$ was larger than that for silica gel particles coated with $\mathrm{TiO}_{2}$ film. Therefore, it revealed that loading was a more effective way to make use of $\mathrm{TiO}_{2}$ for $\mathrm{CO}$ oxidization. However, it also reported that the investigation on optimum experimental condition was necessary to promote the $\mathrm{CO}$ oxidization performance more.

The purpose of this study is to investigate the experimental conditions in order to improve the $\mathrm{CO}$ oxidization performance of mesoporous silica loaded with $\mathrm{TiO}_{2}$.
TABle 1: Physical properties of mesoporous silica loaded with $\mathrm{TiO}_{2}$.

\begin{tabular}{ll}
\hline & $\begin{array}{l}\text { Mesoporous silica } \\
\text { loaded with } \mathrm{TiO}_{2} \text { particles }\end{array}$ \\
\hline Particle size $(\mathrm{mm})$ & $0.03-0.25$ (primary particle) \\
& $2.0-5.6$ (agglomerated particle) \\
Specific surface area $\left(\mathrm{m}^{2} / \mathrm{g}\right)$ & $219-1038$ \\
Average pore diameter $(\mathrm{nm})$ & $2.7-3.1$ \\
Pore volume $(\mathrm{mL} / \mathrm{g})$ & $0.63-0.94$ \\
Ratio of loaded $\mathrm{TiO}_{2}(\mathrm{wt} \%)$ & $1,10,15,20,30,60,80$ \\
\hline
\end{tabular}

Since UV ray can penetrate the mesoporous silica, the particles of mesoporous silica loaded with $\mathrm{TiO}_{2}$ can be used in a bed-type reactor. The effect of loading ratio of $\mathrm{TiO}_{2}$ and initial concentration ratio of $\mathrm{O}_{2}$ to $\mathrm{CO}$ on $\mathrm{CO}$ oxidization performance was investigated to decide the optimum experimental conditions. The loading ratio of $\mathrm{TiO}_{2}$ is changed minutely by $1 \mathrm{wt} \%, 10 \mathrm{wt} \%, 15 \mathrm{wt} \%, 20 \mathrm{wt} \%$, $30 \mathrm{wt} \%, 60 \mathrm{wt} \%$, and $80 \mathrm{wt} \%$. The initial concentration of $\mathrm{O}_{2}$ is also changed closely by $0.5 \mathrm{vol} \%, 1 \mathrm{vol} \%, 2 \mathrm{vol} \%$, $4 \mathrm{vol} \%, 6 \mathrm{vol} \%, 8 \mathrm{vol} \%$, and $10 \mathrm{vol} \%$. Moreover, the best CO oxidization performance of the mesoporous silica with $\mathrm{TiO}_{2}$ was evaluated under the optimum experimental conditions.

\section{Experiment}

2.1. Preparation Method of Mesoporous Silica Loaded with $\mathrm{TiO}_{2}$. Table 1 lists the physical properties of mesoporous silica loaded with $\mathrm{TiO}_{2}$, which has the following characteristics

(i) Average pore size is in nanoscale. Since the molecular diameter of $\mathrm{CO}$ and $\mathrm{O}_{2}$ is relatively close to the average pore diameter, the high adsorption performance is expected.

(ii) $\mathrm{TiO}_{2}$ particle is located inside of pores of the mesoporous silica. Light can pass through mesoporous silica, and gases can also get into the pores of mesoporous silica through the diffusion, therefore, good photocatalytic reaction as well as good adsorption performance can be expected.

Figure 1 shows the preparation method of mesoporous silica particles loaded with $\mathrm{TiO}_{2}$ in our laboratory, which is developed by referring to the literatures [21-23]. P25 (Degussa, P25, JAPAN AEROSIL Corp., LTD.) powder was selected as $\mathrm{TiO}_{2}$ source to load. Because of the primary particle size of P25 which is ranged between $20 \mathrm{~nm}$ and $30 \mathrm{~nm}, \mathrm{P} 25$ is suitable for being inserted into the mesoporous silica particle whose size is ranged between $30 \mathrm{~nm}$ and $100 \mathrm{~nm}$ generally. P25 plays the role of the core for forming mesoporous silica. The pores of mesoporous silica are formed in or around the particles of P25 as illustrated in Figure 2 [23]. Figure 3 shows TEM image of prepared mesoporous silica particles loaded with $\mathrm{TiO}_{2}$ to understand the structure illustrated in Figure 2. The ratio of loaded $\mathrm{TiO}_{2}$ to mesoporous silica was controlled by the amount of P25 added to the mixture solution of ion-exchange water, $\mathrm{CH}_{3}\left(\mathrm{CH}_{2}\right)_{15} \mathrm{~N}\left(\mathrm{CH}_{3}\right)_{3} \mathrm{Br}$ (purity of $99 \mathrm{wt} \%$, Nacalai Tesque 
Corp.), $\left(\mathrm{C}_{2} \mathrm{H}_{5} \mathrm{O}\right)_{4} \mathrm{Si}$ (purity of $95 \mathrm{wt} \%$, Nacalai Tesque Corp.), and $\mathrm{NH}_{3}$ (purity of $28 \mathrm{wt} \%$, Nacalai Tesque Corp.). The amount of P25 particle added to mixture solution was $0.05 \mathrm{~g}, 0.54 \mathrm{~g}, 0.86 \mathrm{~g}, 1.18 \mathrm{~g}, 2.10 \mathrm{~g}, 7.30 \mathrm{~g}$, and $19.5 \mathrm{~g}$ for the ratio of $1 \mathrm{wt} \%, 10 \mathrm{wt} \%, 15 \mathrm{wt} \%, 20 \mathrm{wt} \%, 30 \mathrm{wt} \%$, $60 \mathrm{wt} \%$, and $80 \mathrm{wt} \%$, respectively. Here, the ratio of loaded $\mathrm{TiO}_{2}$ is named after preparation condition since it is very difficult to measure the weight of $\mathrm{TiO}_{2}$ in mesoporous silica particle directly after preparation process. Particle size of agglomerated mesoporous silica particles loaded with $\mathrm{TiO}_{2}$ was sieved into the range between $2.0 \mathrm{~mm}$ and $5.6 \mathrm{~mm}$ after burning.

2.2. Experimental Apparatus and Procedure. Figure 4 illustrates the experimental apparatus which consists of a reactor, a gas mixing chamber, a mass flow controller (MODEL 3660, KOFLOC), a dew point meter (HMT337, VAISALA), a regulator, and a gas cylinder. The reactor, which is a batch type, consists of stainless steel pipe $(450 \mathrm{~mm}(L) \times$. $60.5 \mathrm{~mm}($ O.D. $) \times 2.5 \mathrm{~mm}(t$. $)$; reaction space $50 \mathrm{~mm}(L$. $55.5 \mathrm{~mm}($ I.D. $))$ which includes two acrylic cylinders to cover both ends of UV lamp in it, gas supply and exhaust pipe, valves, gas sampling tap, and UV lamp (FL15BLB, TOSHIBA Co., $436 \mathrm{~mm}\left(L_{.}\right) \times 25.5 \mathrm{~mm}$ (D.)) located at the center of stainless steel pipe. The reaction space for charging gas and filling $\mathrm{TiO}_{2}$ particles is $9.22 \times 10^{4} \mathrm{~mm}^{3}$. The central wavelength and mean light intensity of UV light is $352 \mathrm{~nm}$ and $4.34 \mathrm{~mW} / \mathrm{cm}^{2}$, respectively. This light intensity is almost the same as the UV intensity in solar radiation at daytime in the summer of Japan.

In the experiment, $\mathrm{O}_{2}$ (purity of 99.9999 vol\%) and the premixed gas of $\mathrm{H}_{2}$ and $\mathrm{CO}\left(\mathrm{H}_{2}\right.$ : 99 vol\%, $\mathrm{CO}$ : 1 vol\%) were mixed in the gas mixing chamber before being supplied to the reactor. By adjusting the flow rate and the pressure of the gases, the initial concentration of $\mathrm{O}_{2}$ to $\mathrm{CO}$ could be controlled. This remixed gas was charged into the reactor, and the concentration and pressure of gases were confirmed before starting the experiment. The ratios of gasses were charged as $\mathrm{CO}: \mathrm{O}_{2}=1: 0.5,1: 1,1: 2,1: 4,1: 6,1: 8$, and $1: 10$ (balanced by $\mathrm{H}_{2}$ ). Although $1 \mathrm{~mol} \mathrm{CO}$ reacts with $0.5 \mathrm{~mol} \mathrm{O}_{2}$ theoretically as shown in the reaction of (10), it is necessary to confirm the practical optimum initial concentration ratio of $\mathrm{O}_{2}$ to $\mathrm{CO}$ in rich $\mathrm{H}_{2}$ environment.

The total pressure in the reactor was set at $0.1 \mathrm{MPa}$. The gas temperature in the reactor was kept at about $300 \mathrm{~K}$ during the experiment. Before the mixed gas for $\mathrm{CO}$ oxidization was supplied, mesoporous silica particles loaded with $\mathrm{TiO}_{2}$ were filled into the reactor by 50 vol $\%$ of full reactor volume size.

The experiment was started when illumination of UV light was applied. The gas in reactor was sampled hourly during the experiment. The gas excluding $\mathrm{H}_{2} \mathrm{O}$ vapor samples was analyzed by TCD gas chromatograph (VARIAN microGC CP-4900, GL Science Corp.) equipped with double columns of Molsieve 5A and PoraPLOT Q. The minimum resolution of the gas chromatograph was $1 \mathrm{ppmV}$. The concentration of $\mathrm{H}_{2} \mathrm{O}$ vapor in the experimental apparatus was measured by the dew point meter whose minimum resolution was $1 \mathrm{ppmV}$.

\section{Results and Discussion}

3.1. Effect of Loading Ratio of $\mathrm{TiO}_{2}$ on $\mathrm{CO}$ Oxidization Performance. Figures 5 and 6 show the concentration change of $\mathrm{CO}_{2}$ and $\mathrm{CO}$ with $\mathrm{UV}$ light illumination time for the different loading ratios of $\mathrm{TiO}_{2}$. From these figures, it can be seen that the concentration of $\mathrm{CO}$ for each loading ratio of $\mathrm{TiO}_{2}$ is decreased with the increase of UV light illumination time, while the concentration of $\mathrm{CO}_{2}$ is increased. Although the amount of $\mathrm{CO}$ reduced does not match the amount of $\mathrm{CO}_{2}$ produced which is predicted by (9), the reason of it is that the $\mathrm{CO}$ adsorption performance of prepared mesoporous silica loaded with $\mathrm{TiO}_{2}$ is different among different loading ratios. The increase ratio of $\mathrm{CO}_{2}$ with time is estimated by the following regression line which is derived according to the tendency of data plot:

$$
\left[\mathrm{CO}_{2}\right]=R_{\text {inc- }-\mathrm{CO}_{2}} t
$$

where $\left[\mathrm{CO}_{2}\right]$ is the concentration of $\mathrm{CO}_{2}$ at each time (ppmV), $R_{\text {inc- } \mathrm{CO}_{2}}$ stands for the increase ratio of $\mathrm{CO}_{2}$ $(\mathrm{ppmV} / \mathrm{h})$, and $t$ is the time for UV light illumination (h). According to Figure 5, $R_{\text {inc }-\mathrm{CO}_{2}}$ is $159 \mathrm{ppmV} / \mathrm{h}, 412 \mathrm{ppmV} / \mathrm{h}$, $493 \mathrm{ppmV} / \mathrm{h}, 706 \mathrm{ppmV} / \mathrm{h}, 542 \mathrm{ppmV} / \mathrm{h}, 527 \mathrm{ppmV} / \mathrm{h}$, and $259 \mathrm{ppmV} / \mathrm{h}$ for loading ratio of $\mathrm{TiO}_{2}$ of $1 \mathrm{wt} \%, 10 \mathrm{wt} \%$, $15 \mathrm{wt} \%, 20 \mathrm{wt} \%, 30 \mathrm{wt} \%, 60 \mathrm{wt} \%$, and $80 \mathrm{wt} \%$, respectively. $R_{\text {inc- }} \mathrm{CO}_{2}$ is larger with the increase in loading ratio of $\mathrm{TiO}_{2}$ up to $20 \mathrm{wt} \%$, while it becomes smaller with the increase in loading ratio of $\mathrm{TiO}_{2}$ from $30 \mathrm{wt} \%$. Although the amount of $\mathrm{TiO}_{2}$ loaded in mesoporous silica is increased with the increase in loading ratio of $\mathrm{TiO}_{2}$, which alludes to that the $\mathrm{CO}$ oxidization performance is promoted with the increase in the loading ratio of $\mathrm{TiO}_{2}$, the optimum loading ratio of $\mathrm{TiO}_{2}$ is in the middle ratio.

To compare the oxidization rate of CO, Figure 7 shows the change of residual ratio of $\mathrm{CO}$ with UV light illumination time for different loading ratios of $\mathrm{TiO}_{2}$. The residual ratio of $\mathrm{CO}$ is defined as

$$
R_{\text {res-CO }}=\frac{[\mathrm{CO}]}{[\mathrm{CO}]_{0}} \times 100,
$$

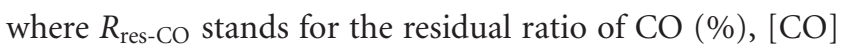
is the concentration of $\mathrm{CO}$ at each time $(\mathrm{ppmV})$, and $[\mathrm{CO}]_{0}$ is the initial concentration of $\mathrm{CO}$ at the beginning of the experiment $(\mathrm{ppmV})$. Regression line is derived according to the tendency of data plot:

$$
R_{\text {res-CO }}=100 \mathrm{e}^{-\alpha t} \text {, }
$$

where $\alpha$ is the coefficient of CO removal $(1 / \mathrm{h})$. According to Figure 7, the $\alpha$ which indicates the oxidization rate of $\mathrm{CO}$ is $9.40 \times 10^{-3}, 8.30 \times 10^{-2}, 1.31 \times 10^{-1}, 1.11 \times 10^{-1}, 1.42$ $\times 10^{-1}, 9.81 \times 10^{-2}$, and $2.54 \times 10^{-2}$, for loading ratio of $\mathrm{TiO}_{2}$ of $1 \mathrm{wt} \%, 10 \mathrm{wt} \%, 15 \mathrm{wt} \%, 20 \mathrm{wt} \%, 30 \mathrm{wt} \%, 60 \mathrm{wt} \%$ and $80 \mathrm{wt} \%$, respectively. $\alpha$ is larger with the increase in loading ratio of $\mathrm{TiO}_{2}$ up to $30 \mathrm{wt} \%$, after that, it is smaller with the increase in loading ratio of $\mathrm{TiO}_{2}$.

Figure 8 shows the comparison of selection ratio of $\mathrm{CO}$ oxidization among different loading ratios of $\mathrm{TiO}_{2}$. 


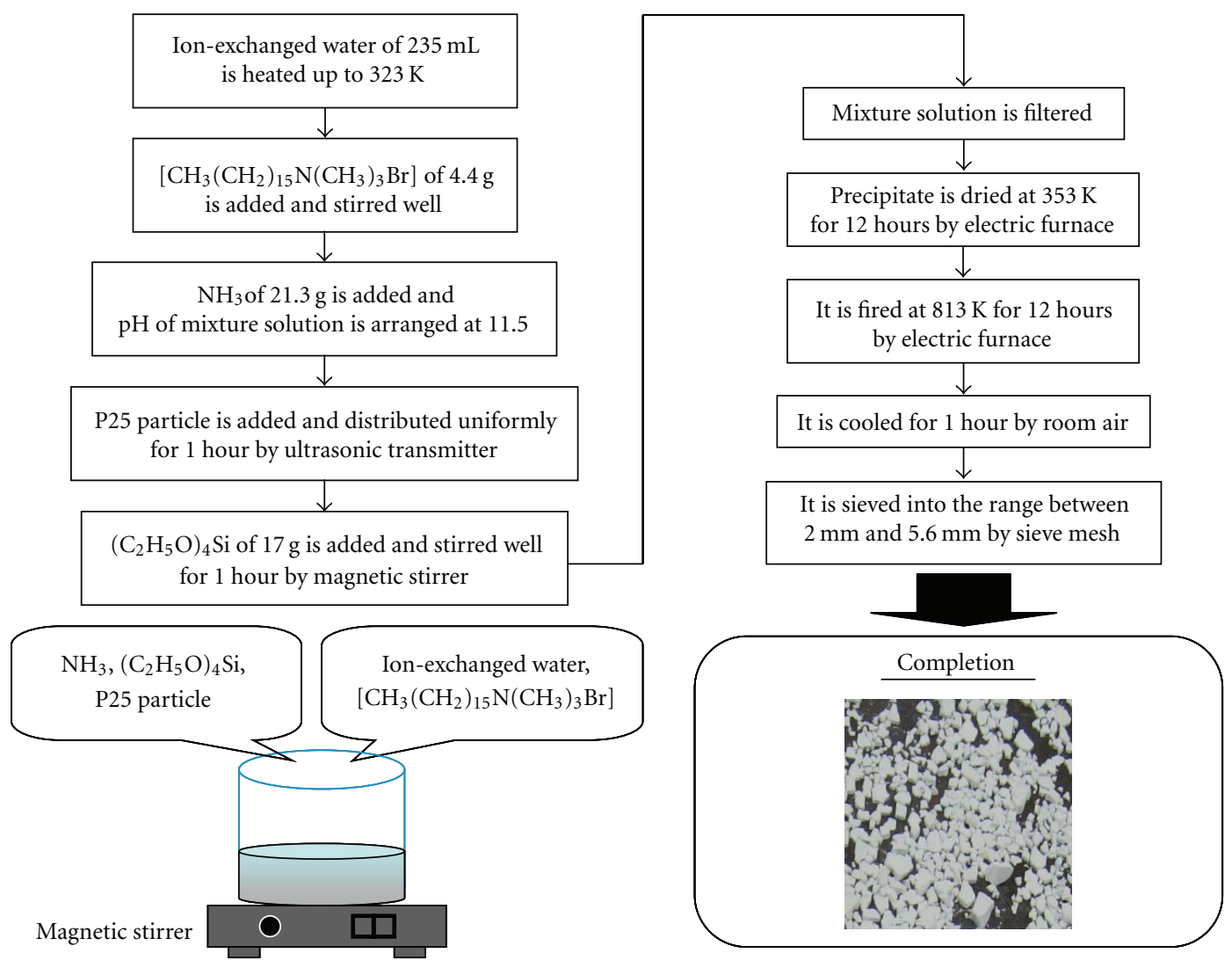

FIgUre 1: Preparation method of mesoporous silica loaded with $\mathrm{TiO}_{2}$.

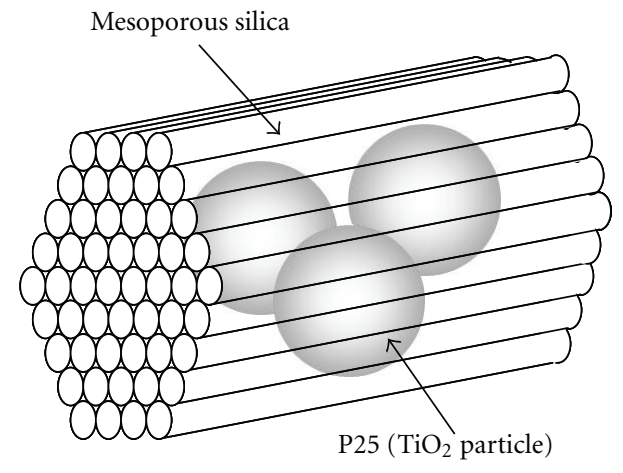

FIGURE 2: Schematic drawing of mesoporous silica loaded with $\mathrm{TiO}_{2}$.

The selection ratio of $\mathrm{CO}$ oxidization is calculated by the following equation:

$$
R_{\text {sel-CO }}=\frac{\left[\mathrm{CO}_{2}\right]-\left[\mathrm{CO}_{2}\right]_{0}}{\left(\left[\mathrm{CO}_{2}\right]-\left[\mathrm{CO}_{2}\right]_{0}\right)+\left(\left[\mathrm{H}_{2} \mathrm{O}\right]-\left[\mathrm{H}_{2} \mathrm{O}\right]_{0}\right)} \times 100,
$$

where $R_{\text {sel-CO }}$ stands for the selection ratio of CO oxidization $(\%),\left[\mathrm{CO}_{2}\right]$ is the concentration of $\mathrm{CO}_{2}$ at each time $(\mathrm{ppmV})$, $\left[\mathrm{CO}_{2}\right]_{0}$ is the initial concentration of $\mathrm{CO}_{2}$ at the beginning of the experiment $(\mathrm{ppmV}),\left[\mathrm{H}_{2} \mathrm{O}\right]$ is the concentration of $\mathrm{H}_{2} \mathrm{O}$ vapor at each time $(\mathrm{ppmV})$, and $\left[\mathrm{H}_{2} \mathrm{O}\right]_{0}$ is the

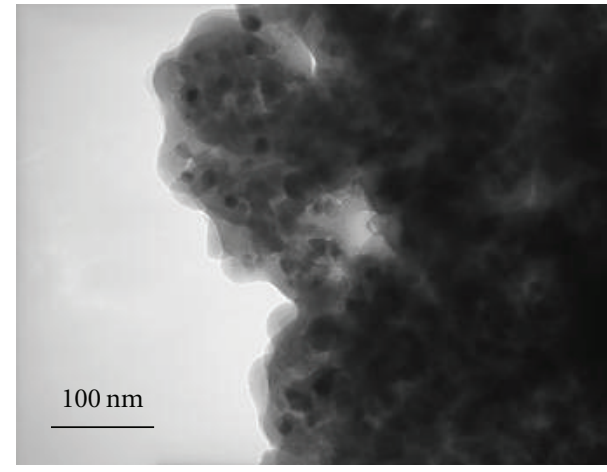

Acceleration voltage: $200 \mathrm{kV}, \times 130.000$

Figure 3: TEM image of mesoporous silica loaded with $\mathrm{TiO}_{2}$ particlesfor the ratio of loaded $\mathrm{TiO}_{2}$ of $15 \mathrm{wt} \%$.

initial concentration of $\mathrm{H}_{2} \mathrm{O}$ vapor at the beginning of the experiment $(\mathrm{ppmV})$. In this study, the selection ratio of $\mathrm{CO}$ oxidization means the ratio of amount of $\mathrm{CO}_{2}$ to total oxide.

From this figure, it is known that the middle loading ratios are better compared with the lower and higher loading ratio conditions. Above all, the best selection ratio of $\mathrm{CO}$ oxidization is obtained for the loading ratio of $\mathrm{TiO}_{2}$ of $20 \mathrm{wt} \%$. Considering the results including $R_{\mathrm{inc}-\mathrm{CO}_{2}}$ and $\alpha$, it can be said that mesoporous silica loaded with $\mathrm{TiO}_{2}$ has 
(6)

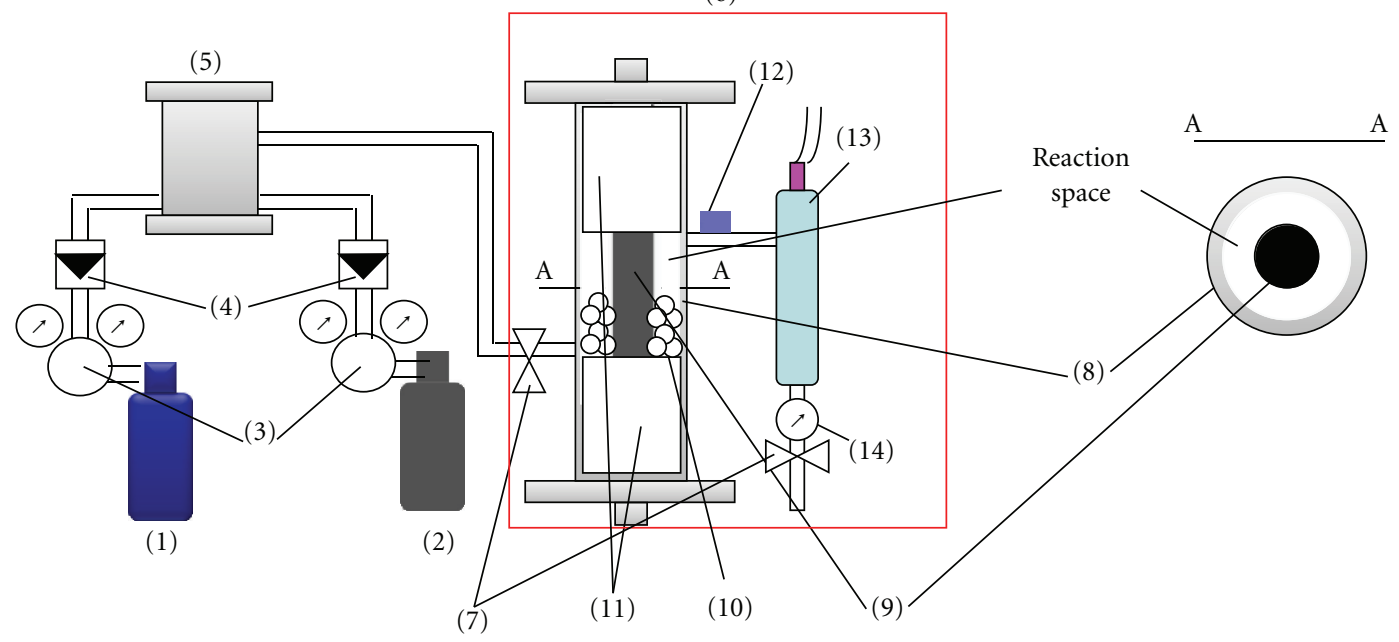

(1) Premixed gas cylinder

$\left(\mathrm{H}_{2}: 99 \mathrm{vol} \%\right.$, $\left.\mathrm{CO}: 1 \mathrm{vol} \%\right)$

(6) Reactor

(11) Acrylic cylinder

(2) $\mathrm{O}_{2}$ gas cylinder

(7) Valve

(12) Sampling tap

(99.9999 vol\%)

(3) Regulator

(8) Stainless pipe

(13) Dew point meter

(4) Mass flow controller

(9) UV lamp

(14) Pressure meter

(5) Gas mixing chamber

(10) $\mathrm{TiO}_{2}$ combined with silica

FIgURE 4: Experimental apparatus.

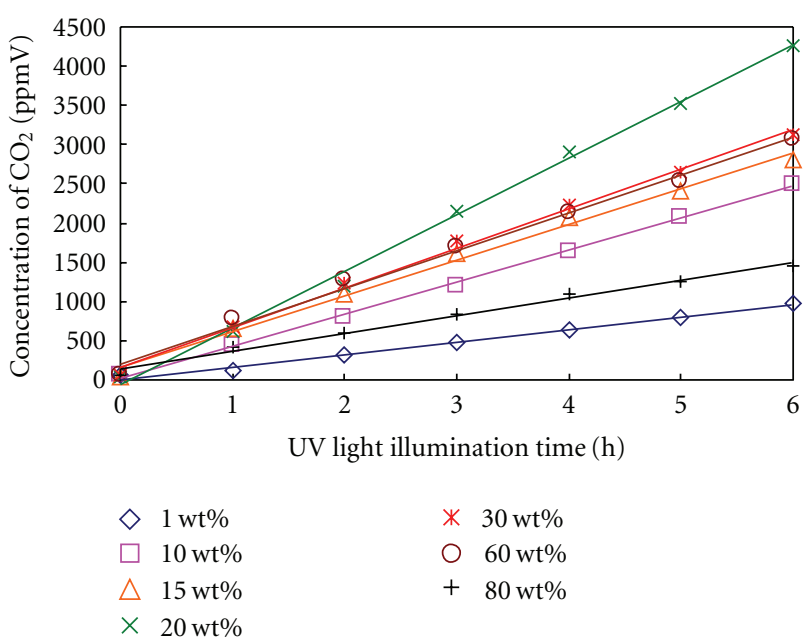

FIGURE 5: Change of concentration of $\mathrm{CO}_{2}$ with UV light illumination time for different loading ratios of $\mathrm{TiO}_{2}$.

the best $\mathrm{CO}$ oxidization performance in the middle loading ratio, that is, around $20 \mathrm{wt} \%$. According to our previous study [20], the amount of $\mathrm{TiO}_{2}$, that is, the number of $\mathrm{TiO}_{2}$ particle in mesoporous silica is increased with the increase in loading ratio of $\mathrm{TiO}_{2}$. However, the adsorption performance of mesoporous silica loaded with $\mathrm{TiO}_{2}$ is dropped with the increase in loading ratio of $\mathrm{TiO}_{2}$ due to the pore diameter expansion and the weakening of the honeycomb shape

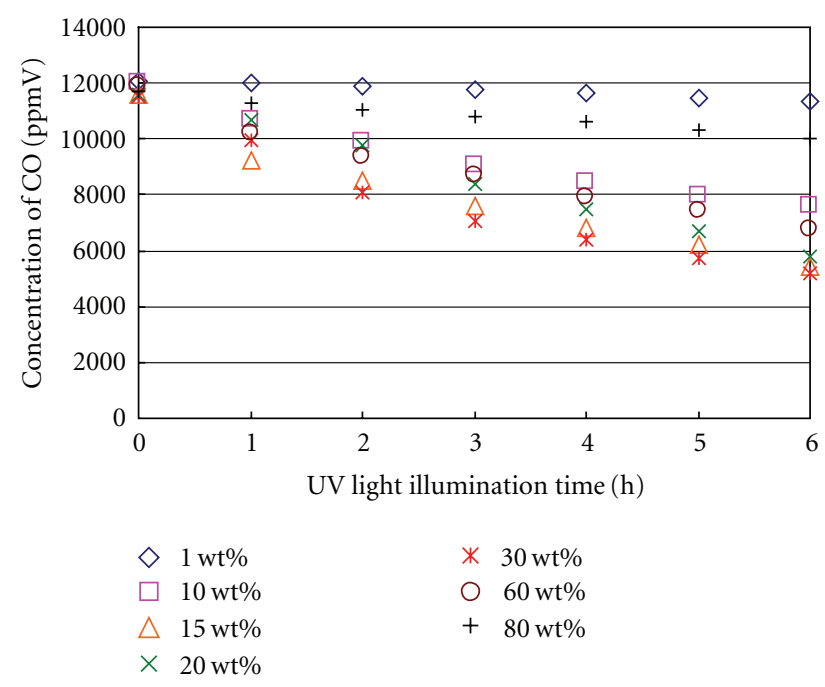

FIGURE 6: Change of concentration of CO with UV light illumination time for different loading ratios of $\mathrm{TiO}_{2}$.

of mesoporous silica by increased loaded $\mathrm{TiO}_{2}$. Therefore, it can be thought that the best match loading condition between high photocatalytic reaction performance and high adsorption performance is obtained in the middle loading ratio for the mesoporous silica loaded with $\mathrm{TiO}_{2}$.

To evaluate the $\mathrm{CO}$ oxidization performance of mesoporous silica loaded with $\mathrm{TiO}_{2}$ from diverse view points, the summation of the performance comparison factor $F$ which is 


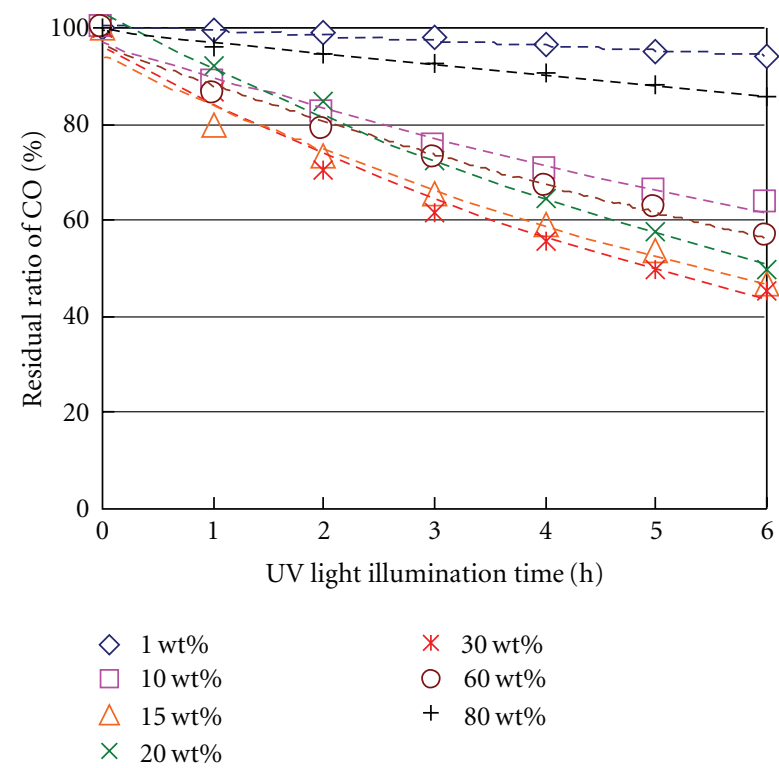

FIgure 7: Residual ratio of CO for different loading ratio of $\mathrm{TiO}_{2}$.

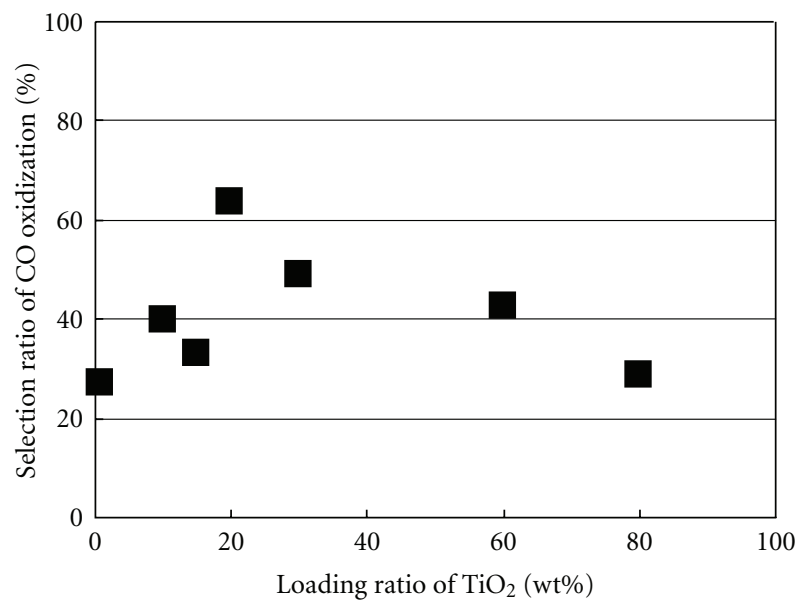

Figure 8: Comparison of selection ratio of $\mathrm{CO}$ oxidization among different loading ratio of $\mathrm{TiO}_{2}$.

calculated by (15) is introduced:

$$
F=\frac{\text { Index }_{\text {each }}-\text { Index }_{\text {ave }}}{\text { Index }},
$$

where Index $\mathrm{each}_{\text {and }}$ Index $\mathrm{x}_{\mathrm{ave}}$ stand for the value of evaluation index on $\mathrm{CO}$ oxidization performance such as $R_{\mathrm{inc}-\mathrm{CO}_{2}}, \alpha$, and $R_{\text {sel-CO }}$ under each loading ratio of $\mathrm{TiO}_{2}$, and the average value of evaluation index on $\mathrm{CO}$ oxidization performance among all loading ratios of $\mathrm{TiO}_{2}$, respectively. Here, the data after UV light illumination of 6 hours are used to calculate $F$ for $\alpha$ and $R_{\text {sel-CO. }}$.

Table 2 lists $F$ and the summation of $F$ for each loading ratio of $\mathrm{TiO}_{2}$. From this table, it reveals that the loading ratio of $\mathrm{TiO}_{2}$ of $20 \mathrm{wt} \%$ is the best loading condition. Although the middle loading ratio of $\mathrm{TiO}_{2}$ was clarified to be suitable for $\mathrm{CO}$ oxidization in our previous study [20], the current

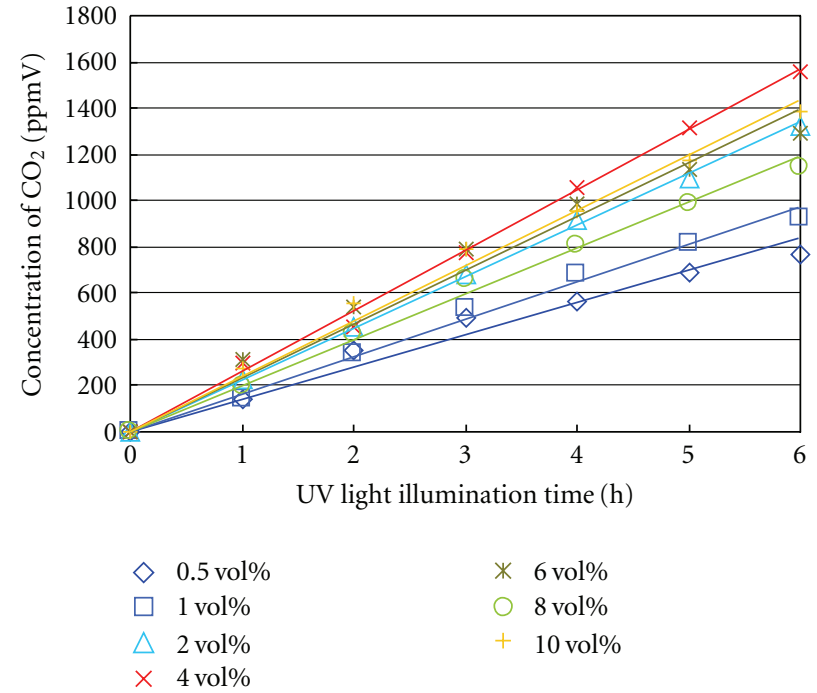

FIGURE 9: Change of concentration of $\mathrm{CO}_{2}$ with UV light illumination time for different initial concentrations of $\mathrm{O}_{2}$.

study confirms that the loading ratio of $\mathrm{TiO}_{2}$ of $20 \mathrm{wt} \%$ is the optimum loading ratio for the promotion of the $\mathrm{CO}$ oxidization performance of mesoporous silica loaded with $\mathrm{TiO}_{2}$.

3.2. Effect of Initial Ratio of $\mathrm{O}_{2}$ to $\mathrm{CO}$ on $\mathrm{CO}$ Oxidization Performance. Figures 9 and 10 show the concentration change of $\mathrm{CO}_{2}$ and $\mathrm{CO}$ with UV light illumination time for the different initial concentrations of $\mathrm{O}_{2}$. From these figures, it can be seen that the concentration of $\mathrm{CO}$ for each initial concentration of $\mathrm{O}_{2}$ is decreased with the increase in UV light illumination time, while the concentration of $\mathrm{CO}_{2}$ is increased. According to Figure $9, R_{\text {inc- }-\mathrm{CO}_{2}}$ is $139 \mathrm{ppmV} / \mathrm{h}, 162 \mathrm{ppmV} / \mathrm{h}, 223 \mathrm{ppmV} / \mathrm{h}, 260 \mathrm{ppmV} / \mathrm{h}$, $232 \mathrm{ppmV} / \mathrm{h}, 198 \mathrm{ppmV} / \mathrm{h}$, and $239 \mathrm{ppmV} / \mathrm{h}$ for initial concentration of $\mathrm{O}_{2}$ of $0.5 \mathrm{vol} \%, 1 \mathrm{vol} \%, 2 \mathrm{vol} \%, 4 \mathrm{vol} \%, 6 \mathrm{vol} \%$, $8 \mathrm{vol} \%$, and $10 \mathrm{vol} \%$, respectively. Figure 11 shows the change of residual ratio of $\mathrm{CO}$ with UV light illumination time for different initial concentrations of $\mathrm{O}_{2} . \alpha$ is $1.43 \times$ $10^{-2}, 2.88 \times 10^{-2}, 4.62 \times 10^{-2}, 5.23 \times 10^{-2}, 4.00 \times 10^{-2}$, $3.97 \times 10^{-2}$, and $4.43 \times 10^{-2}$ for initial concentration of $\mathrm{O}_{2}$ of $0.5 \mathrm{vol} \%, 1 \mathrm{vol} \%, 2 \mathrm{vol} \%, 4 \mathrm{vol} \%, 6 \mathrm{vol} \%, 8 \mathrm{vol} \%$ and $10 \mathrm{vol} \%$, respectively. From these results, it is confirmed that the initial concentration of $\mathrm{O}_{2}$ exceeding the stoichiometric ratio, that is, $0.5 \mathrm{vol} \%$, is necessary. In addition, $R_{\text {inc- }-\mathrm{CO}_{2}}$ and $\alpha$ are increased with the initial concentration of $\mathrm{O}_{2}$ up to $4 \mathrm{vol} \%$ and decreased over 4 vol\%. Since the experimental apparatus in this study is a batch type and forcible gas mixing is not carried out, it might be thought that excess amount of $\mathrm{O}_{2}$ is necessary for $\mathrm{O}_{2}$ to contact with $\mathrm{CO}$ near the surface of mesoporous silica particle loaded with $\mathrm{TiO}_{2}$. However, the excess amount of $\mathrm{O}_{2}$ is thought also to block the diffusions of $\mathrm{CO}$ to the surface and $\mathrm{CO}_{2}$ from the surface. Consequently, there is an optimum initial concentration of $\mathrm{O}_{2}$ existing.

Figure 12 shows the comparison of selection ratio of $\mathrm{CO}$ oxidization among different initial concentrations of $\mathrm{O}_{2}$. 
TABLE 2: Comparison of $F$ and the summation of $F$ for each loading ratio of $\mathrm{TiO}_{2}$.

\begin{tabular}{|c|c|c|c|c|}
\hline & & $F(-)$ & & $\sum F(-)$ \\
\hline Loading ratio of $\mathrm{TiO}_{2}(\mathrm{wt} \%)$ & $R_{\text {inc- }-\mathrm{CO}_{2}}$ & $\alpha$ & $R_{\text {sel-CO }}$ & \\
\hline 1 & -0.60 & -0.87 & -0.29 & -1.76 \\
\hline 10 & 0.027 & 0.11 & 0.045 & 0.18 \\
\hline 15 & 0.23 & 0.75 & -0.13 & 0.85 \\
\hline 20 & 0.76 & 0.48 & 0.67 & 1.91 \\
\hline 30 & 0.35 & 0.89 & 0.29 & 1.53 \\
\hline 60 & 0.31 & 0.31 & 0.11 & 0.73 \\
\hline 80 & -0.35 & -0.66 & -0.25 & -1.26 \\
\hline
\end{tabular}

TABLE 3: Comparison of $F$ and the summation of $F$ for each initial concentration of $\mathrm{O}_{2}$.

\begin{tabular}{|c|c|c|c|c|}
\hline & & $F(-)$ & & $\sum F(-)$ \\
\hline Initial concentration of $\mathrm{O}_{2}(\mathrm{vol} \%)$ & $R_{\text {inc-CO }}$ & $\alpha$ & $R_{\text {sel-CO }}$ & \\
\hline 0.5 & -0.33 & -0.62 & -0.37 & -1.32 \\
\hline 1 & -0.22 & -0.24 & -0.32 & -0.78 \\
\hline 2 & 0.074 & 0.22 & 0.23 & 0.52 \\
\hline 4 & 0.25 & 0.38 & 0.35 & 0.98 \\
\hline 6 & 0.12 & 0.054 & 0.29 & 0.46 \\
\hline 8 & -0.046 & 0.046 & -0.17 & -0.17 \\
\hline 10 & 0.15 & 0.17 & -0.013 & 0.31 \\
\hline
\end{tabular}

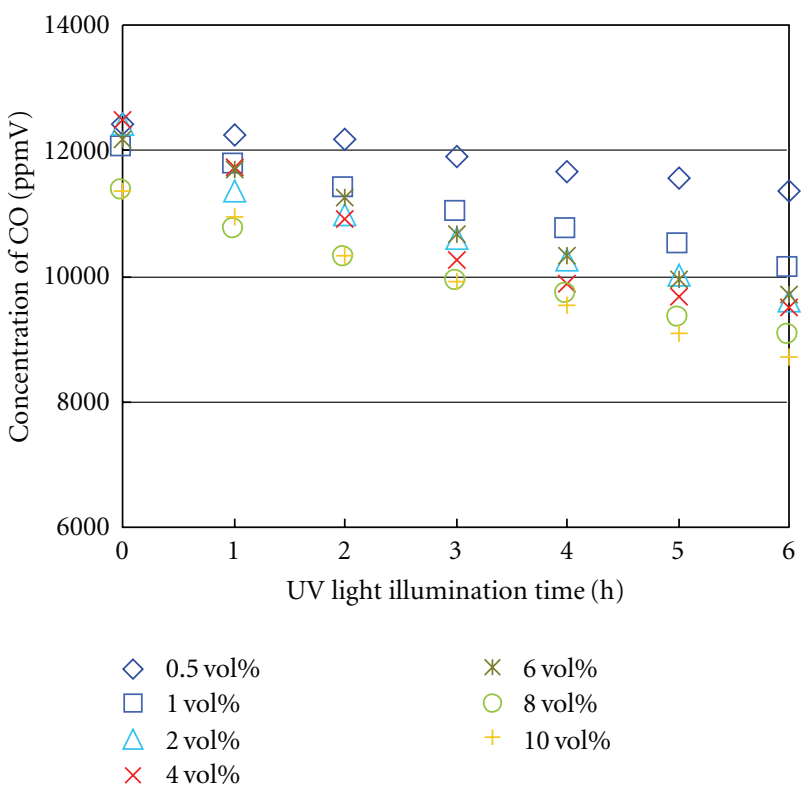

FIGURE 10: Change of concentrations of CO with UV light illumination time for different initial concentrations of $\mathrm{O}_{2}$.

From this figure, it is known that the best selection ratio of $\mathrm{CO}$ oxidization is obtained for the initial concentration of $\mathrm{O}_{2}$ of $4 \mathrm{vol} \%$, the same as the results of $R_{\text {inc- }-\mathrm{CO}_{2}}$ and $\alpha$ as described above. With the lower initial concentration of $\mathrm{O}_{2}$, it seems that the $\mathrm{CO}$ oxidization performance is not good due to lack of gas supply to the reaction surface as mentioned above. On the other hand, $\mathrm{CO}$ oxidization performance declines at the higher initial concentration of $\mathrm{O}_{2}$. Since $\mathrm{H}_{2} \mathrm{O}$ that is a byproduct in this reaction is

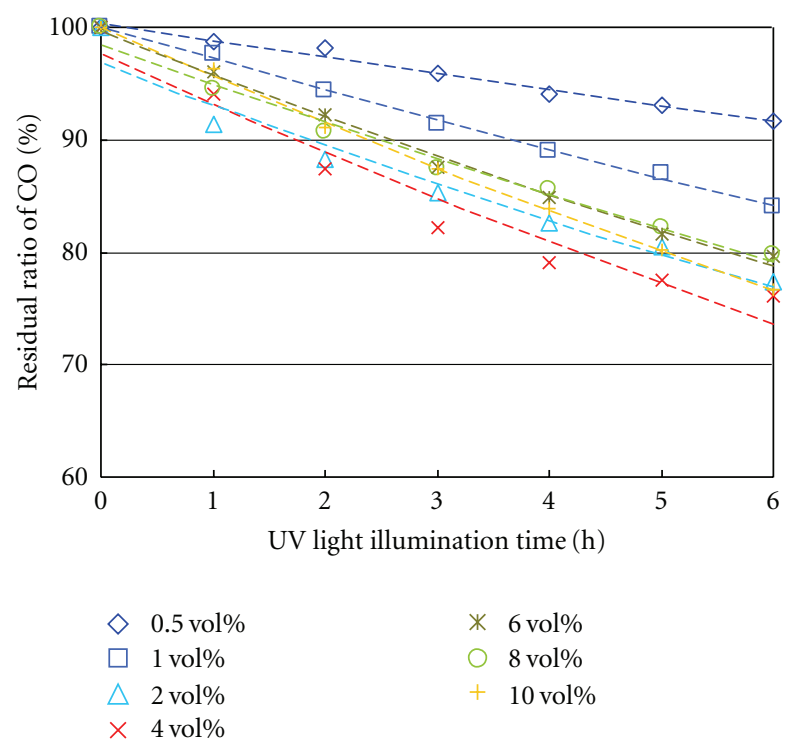

FIGURE 11: Residual ratio of CO for different initial concentrations of $\mathrm{O}_{2}$.

adsorbed by mesoporous silica more easily than $\mathrm{CO}, \mathrm{O}_{2}$ and $\mathrm{CO}_{2}$ [24], the $\mathrm{CO}$ adsorption by mesoporous silica might be dropped under the higher initial concentration of $\mathrm{O}_{2}$. Therefore, the $\mathrm{CO}$ oxidization performance of mesoporous silica loaded with $\mathrm{TiO}_{2}$ also declines. Consequently, the optimum initial concentration of $\mathrm{O}_{2}$ is in the middle level of initial concentration of $\mathrm{O}_{2}$. Table 3 lists $F$ and the summation of $F$ for each initial concentration of $\mathrm{O}_{2}$. From this table, it is revealed that the initial concentration of $\mathrm{O}_{2}$ of $4 \mathrm{vol} \%$ 


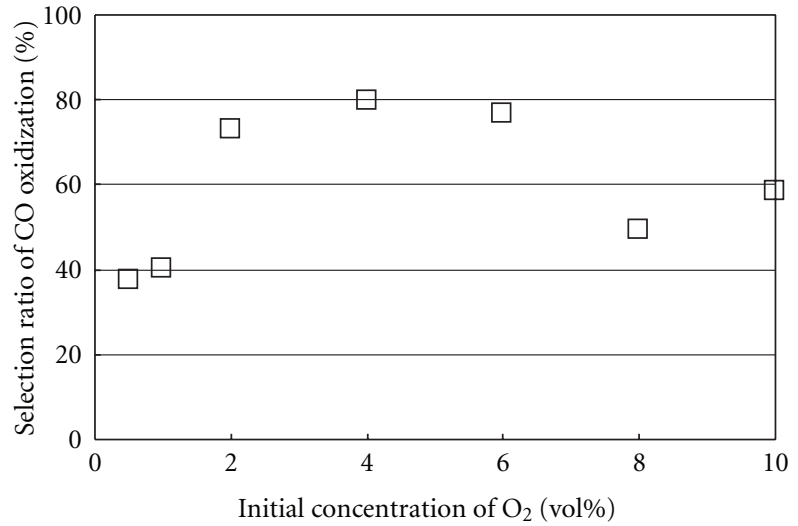

FIGURE 12: Comparison of selection ratio of CO oxidization among different initial concentrations of $\mathrm{O}_{2}$.

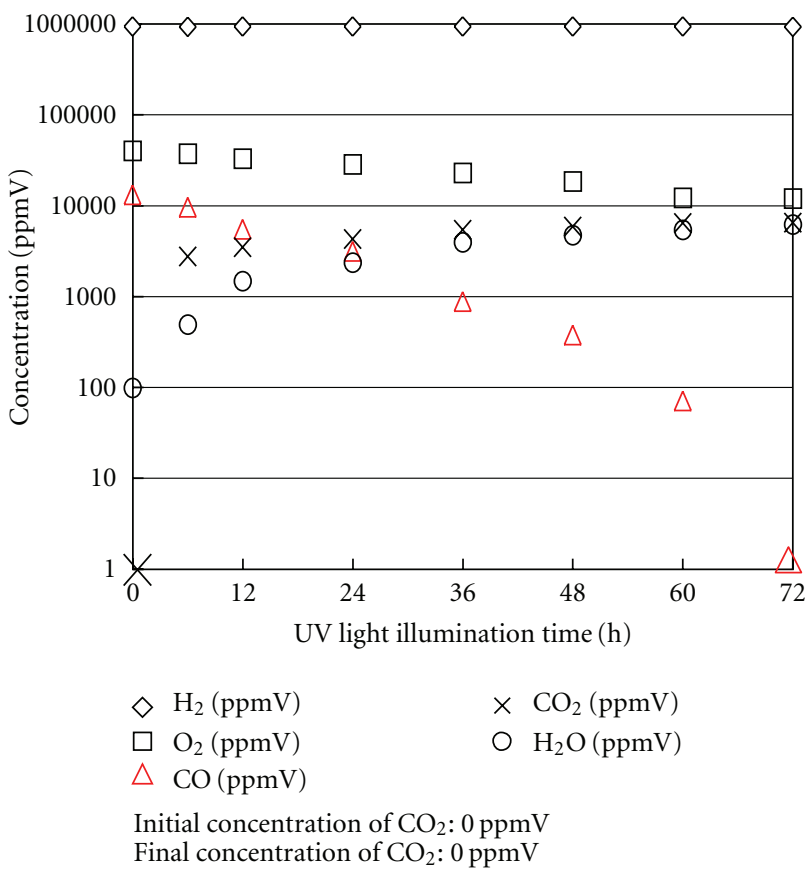

FIGURE 13: Change of each gas concentration with UV light illumination time in the long time experiment (loading ratio of $\mathrm{TiO}_{2}$ of $20 \mathrm{wt} \%$, initial concentrations of $\mathrm{O}_{2}$ of 4 vol\%).

is also the best initial concentration from diverse view points. Therefore, the optimum initial concentration of $\mathrm{O}_{2}$ to promote the $\mathrm{CO}$ oxidization performance of mesoporous silica loaded with $\mathrm{TiO}_{2}$ is decided at $4 \mathrm{vol} \%$.

\subsection{Evaluation on the Maximum CO Oxidization Performance} of Mesoporous Silica Loaded with $\mathrm{TiO}_{2}$. The above described results are evaluated by UV light illumination of 6 hours. To evaluate the maximum $\mathrm{CO}$ oxidization performance of mesoporous silica loaded with $\mathrm{TiO}_{2}$, a longer time experiment was carried out under the optimum experimental condition as decided above.
Figure 13 shows the change of each gas concentration with UV light illumination time in the long time experiment with loading ratio of $\mathrm{TiO}_{2}$ of $20 \mathrm{wt} \%$ and initial concentration of $\mathrm{O}_{2}$ of $4 \mathrm{vol} \%$. From this figure, the concentration of $\mathrm{CO}$ could decrease from $12000 \mathrm{ppmV}$ down to $0 \mathrm{ppmV}$ after UV light illumination time of 72 hours. In other words, although taking longer time, the CO was finally eliminated, which is comparable or superior to the results of the other CO oxidization processes $[18,19,25,26]$. This proves that the proposed technology of $\mathrm{TiO}_{2}$ combined with silica is a promising alternative $\mathrm{CO}$ oxidization process. To promote the $\mathrm{CO}$ oxidization performance of mesoporous silica loaded with $\mathrm{TiO}_{2}$, that is, to promote the $\mathrm{CO}$ oxidization rate further, the investigation on the gas supply and adsorption control and UV light illumination intensity in reactor is thought to be the next subject to study.

\section{Conclusions}

Based on the above experimental results and discussion, the following conclusions can be drawn from this experimental study.

The optimum loading ratio of $\mathrm{TiO}_{2}$ is around $20 \mathrm{wt} \%$ and the optimum initial concentration of $\mathrm{O}_{2}$ is $4 \mathrm{vol} \%$ from the viewpoint of best matching of reaction rate of $\mathrm{CO}$ oxidization and selection ratio of $\mathrm{CO}$ oxidization. The best match loading condition between high photocatalytic reaction performance and high adsorption performance is in the middle loading ratio for the mesoporous silica loaded with $\mathrm{TiO}_{2}$.

The initial concentration of $\mathrm{O}_{2}$ in excess of the stoichiometric ratio is necessary to ensure enough gas supplied to the reaction surface. However, too much excess initial concentration of $\mathrm{O}_{2}$ would cause the block of gas diffusion to or from the surface which undermines the CO adsorption performance and would produce too much water that was more easily adsorbed by the mesoporous silica particle loaded with $\mathrm{TiO}_{2}$, resulting in the drop of the $\mathrm{CO}$ oxidization performance.

The $\mathrm{CO}$ of $12000 \mathrm{ppmV}$ in the rich $\mathrm{H}_{2}$ could be completely oxidized after UV light illumination time of 72 hours, which is comparable with the other $\mathrm{CO}$ removal methods.

\section{References}

[1] Formenti M. and S. J. Teichner, Catalysis, Specialist Periodical Report, The Chemical Society, London, UK, 1978.

[2] S. Sato, T. Kadowaki, and K. Yamaguchi, "Photo-isotope exchange between lattice oxygen and gaseous phase oxygen of oxide semiconductor-relationship with photocatalytic activity," Catalyst, vol. 27, no. 6, pp. 446-448, 1985.

[3] U.S. Department of the Interior and U.S. Geological Survey, Mineral Commodity Summaries 2006, United States Government Printing Office, Washington, DC, USA, 2006.

[4] J. Zhang, M. Minagawa, M. Matsuoka, H. Yamashita, and M. Anpo, "Photocatalytic decomposition of NO on Ti-HMS mesoporous zeolite catalysts," Catalysis Letters, vol. 66, no. 4, pp. 241-243, 2000. 
[5] H. Kominami, K. Yukishita, T. Kimura et al., "Direct solvothermal formation of nanocrystalline $\mathrm{TiO}_{2}$ on porous $\mathrm{SiO}_{2}$ adsorbent and photocatalytic removal of nitrogen oxides in air over $\mathrm{TiO}_{2}-\mathrm{SiO}_{2}$ composites," Topics in Catalysis, vol. 47, no. 3-4, pp. 155-161, 2008.

[6] T. H. Lim and S. D. Kim, "Photocatalytic reduction of NO by $\mathrm{CO}$ over $\mathrm{TiO}_{2} /$ Silica gel in an annulus fluidized bed photoreactor," Journal of the Chinese Institute of Chemical Engineers, vol. 36, no. 1, pp. 85-89, 2005.

[7] Y. G. Shul, H. J. Kim, S. J. Haam, and H. S. Han, "Photocatalytic characteristics of $\mathrm{TiO}_{2}$ supported on $\mathrm{SiO}_{2}$," Research on Chemical Intermediates, vol. 29, no. 7-9, pp. 849-859, 2003.

[8] C. Cantau, T. Pigot, R. Brown et al., "Photooxidation of dimethylsulfide in the gas phase: a comparison between $\mathrm{TiO}_{2}$-silica and photosensitizer-silica based materials," Applied Catalysis B, vol. 65, no. 1-2, pp. 77-85, 2006.

[9] K. Yamaguchi, K. Inumaru, Y. Oumi, T. Sano, and S. Yamanaka, "Photocatalytic decomposition of 2-propanol in air by mechanical mixtures of $\mathrm{TiO}_{2}$ crystalline particles and silicalite adsorbent: the complete conversion of organic molecules strongly adsorbed within zeolitic channels," Microporous and Mesoporous Materials, vol. 117, no. 1-2, pp. 350$355,2009$.

[10] G. R. M. Echavia, F. Matzusawa, and N. Negishi, "Photocatalytic degradation of organophosphate and phosphonoglycine pesticides using $\mathrm{TiO}_{2}$ immobilized on silica gel," Chemosphere, vol. 76, no. 5, pp. 595-600, 2009.

[11] K. Ikeue, H. Yamashita, and M. Anpo, "Photocatalytic reduction of $\mathrm{CO}_{2}$ with $\mathrm{H}_{2} \mathrm{O}$ on titanium oxides prepared within zeolites and mesoporous molecular sieves," Electrochemistry, vol. 70, no. 6, pp. 402-408, 2002.

[12] H. Yamashita, "Photocatalytic action of highly dispersion $\mathrm{TiO}_{2}$ prepared within pore of zeolite," in Proceedings of the 80th Catalytic Society of Japan Meeting Abstracts (CATSJ '97), vol. 39, pp. 414-415, 1997.

[13] K. I. Tanaka, Y. Moro-Oka, K. Ishigure et al., "A new catalyst for selective oxidation of $\mathrm{CO}$ in $\mathrm{H}_{2}$ : part 1 , activation by depositing a large amount of $\mathrm{FeO}$ on $\mathrm{Pt} / \mathrm{Al}_{2} \mathrm{O}_{3}$ and $\mathrm{Pt} / \mathrm{CeO}_{2}$ catalysts," Catalysis Letters, vol. 92, no. 3-4, pp. 115-121, 2004.

[14] M. Shou, K. I. Tanaka, K. Yoshioka, Y. Moro-Oka, and S. Nagano, "New catalyst for selective oxidation of CO in excess $\mathrm{H}_{2}$ designing of the active catalyst having different optimum temperature," Catalysis Today, vol. 90, no. 3-4, pp. 255-261, 2004.

[15] K. Tanaka and M. Shou, "Promotion effect of $\mathrm{H}_{2}$ and $\mathrm{H}_{2} \mathrm{O}$ on CO oxidization Reaction," in Proceedings of the 96th Catalytic Society of Japan Meeting Abstracts (CATSJ '05), vol. 47, pp. 418-420, 2005.

[16] M. Watanabe, H. Uchida, H. Igarashi, and M. Suzuki, "Pt catalyst supported on zeolite for selective oxidation of CO in reformed gases," Chemistry Letters, pp. 21-22, 1995.

[17] H. Igarashi, H. Uchida, M. Suzuki, Y. Sasaki, and M. Watanabe, "Removal of carbon monoxide from hydrogen-rich fuels by selective oxidation over platinum catalyst supported on zeolite," Applied Catalysis A, vol. 159, no. 1-2, pp. 159-169, 1997.

[18] T. Kamegawa, R. Takeuchi, M. Matsuoka, and M. Anpo, "Photocatalytic oxidation of CO with various oxidants by Mo oxide species highly dispersed on $\mathrm{SiO}_{2}$ at $293 \mathrm{~K}$," Catalysis Today, vol. 111, no. 3-4, pp. 248-253, 2006.

[19] T. Kamegawa, M. Matsuoka, and M. Anpo, "Photocatalytic selective oxidation of $\mathrm{CO}$ with $\mathrm{O}_{2}$ in the presence of $\mathrm{H}_{2}$ over highly dispersed chromium oxide on silica under visible or solar light irradiation," Research on Chemical Intermediates, vol. 34, no. 4, pp. 427-434, 2008.

[20] A. Nishimura, T. Hisada, M. Hirota, M. Kubota, and E. Hu, "Using $\mathrm{TiO}_{2}$ photocatalyst with adsorbent to oxidize carbon monoxide in rich hydrogen," Catalysis Today, vol. 158, no. 34, pp. 296-304, 2010.

[21] K. Inumaru, M. Murashima, T. Kasahara, and S. Yamanaka, "Enhanced photocatalytic decomposition of 4-nonylphenol by surface-organografted $\mathrm{TiO}_{2}$ : a combination of molecular selective adsorption and photocatalysis," Applied Catalysis B, vol. 52, no. 4, pp. 275-280, 2004.

[22] T. Kasahara, K. Inumaru, and S. Yamanaka, "Enhanced photocatalytic decomposition of nonylphenol polyethoxylate by alkyl-grafted $\mathrm{TiO}_{2}-\mathrm{MCM}-41$ organic-inorganic nanostructure," Microporous and Mesoporous Materials, vol. 76, no. 1-3, pp. 123-130, 2004.

[23] K. Inumaru, T. Kasahara, M. Yasui, and S. Yamanaka, "Direct nanocomposite of crystalline $\mathrm{TiO}_{2}$ particles and mesoporous silica as a molecular selective and highly active photocatalyst," Chemical Communications, no. 16, pp. 2131-2133, 2005.

[24] S. Y. Jeong, H. Jin, J. M. Lee, and D. J. Yim, "Adsorption on Ti-and Al-containing mesoporous materials prepared from fluorosilicon," Microporous and Mesoporous Materials, vol. 4445, pp. 717-723, 2001.

[25] W. Zhang, Y. Huang, J. Wang et al., " $\mathrm{IrFeO} / \mathrm{SiO}_{2}$-a highly active catalyst for preferential $\mathrm{CO}$ oxidation in $\mathrm{H}_{2}$," International Journal of Hydrogen Energy, vol. 35, no. 7, pp. 3065-3071, 2010.

[26] N. Maeda, T. Matsushima, M. Kotobuki et al., " $\mathrm{HO}_{2}$-tolerant monolithic catalysts for preferential oxidation of carbon monoxide in the presence of hydrogen," Applied Catalysis A, vol. 370, no. 1-2, pp. 50-53, 2009. 


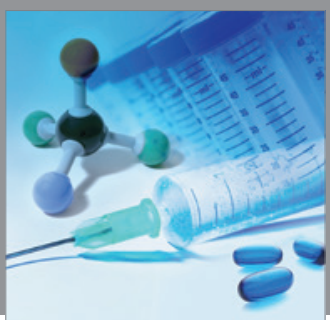

International Journal of

Medicinal Chemistry

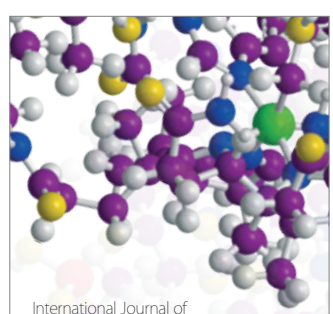

Carbohydrate Chemistry

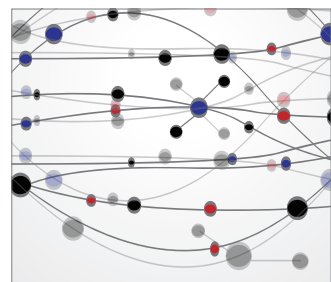

The Scientific World Journal
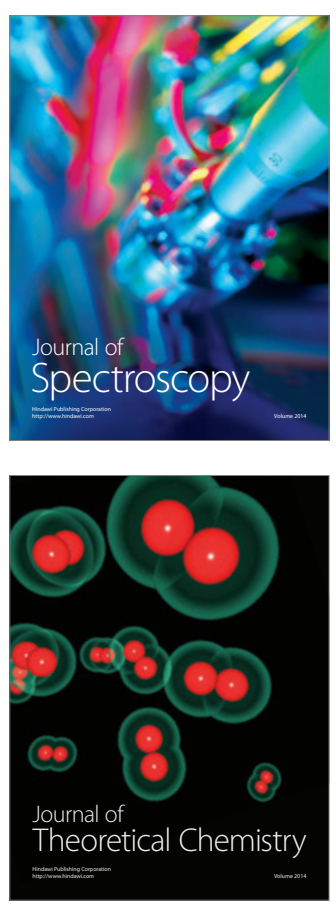
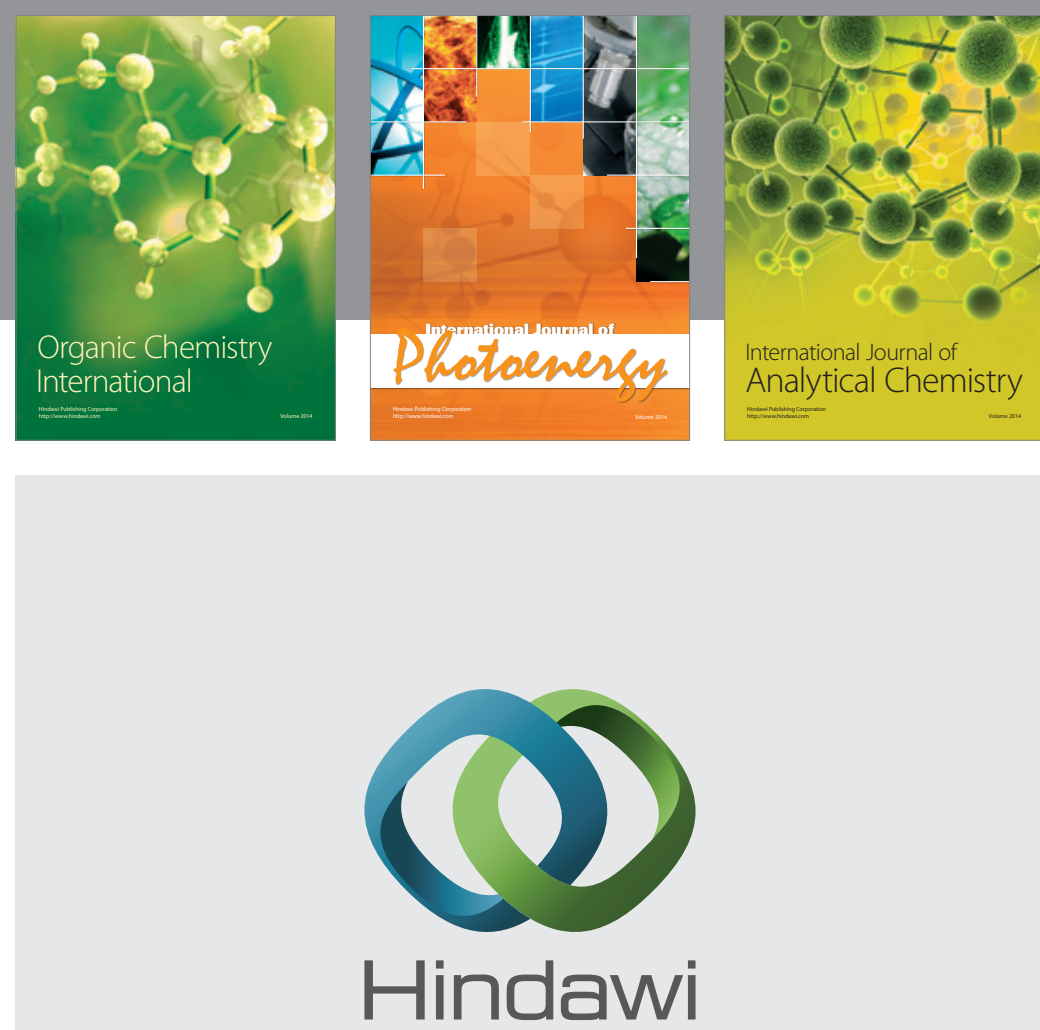

Submit your manuscripts at

http://www.hindawi.com
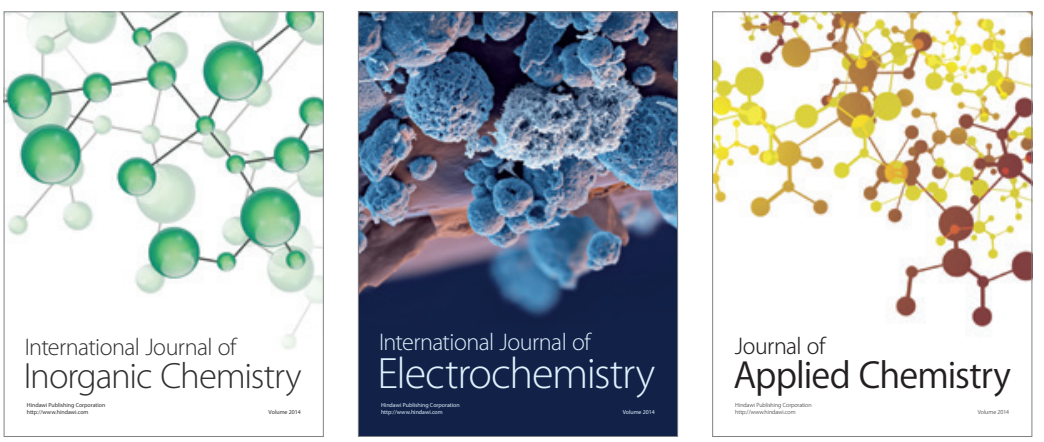

Journal of

Applied Chemistry
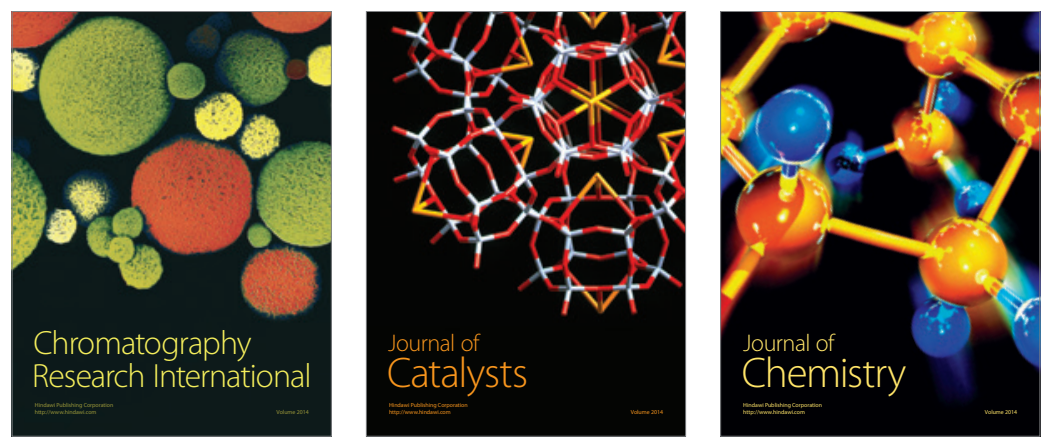
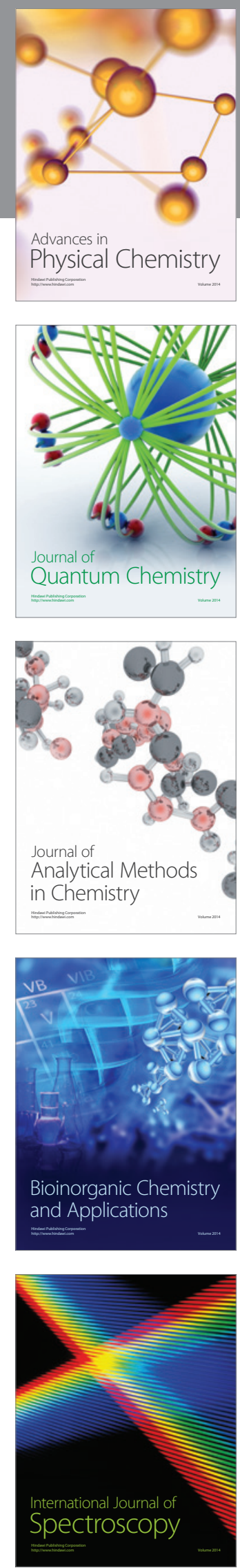